\title{
Processes of lithosphere evolution
} new evidence on the structure of the continental crust and uppermost mantle

Artemieva, Irina; Mooney, W.D.; Perchuc, E.; Thybo, Hans

Published in:

Tectonophysics

Publication date:

2002

Document version

Early version, also known as pre-print

Citation for published version (APA):

Artemieva, I., Mooney, W. D., Perchuc, E., \& Thybo, H. (2002). Processes of lithosphere evolution: new evidence on the structure of the continental crust and uppermost mantle. Tectonophysics, 358, 1-15. 


\title{
Processes of lithosphere evolution: new evidence on the structure of the continental crust and uppermost mantle
}

\author{
Irina M. Artemieva ${ }^{\mathrm{a}, *}$, Walter D. Mooney ${ }^{\mathrm{b}}$, Edward Perchuc $^{\mathrm{c}}$, Hans Thybo ${ }^{\mathrm{d}}$ \\ ${ }^{a}$ Institut de Physique du Globe, EOST, 5, Rue Rene Descartes, Strasbourg cedex F-67084, France \\ ${ }^{\mathrm{b}}$ U.S. Geological Survey, Menlo Park, CA, USA \\ ${ }^{\mathrm{c}}$ Institute of Geophysics, Warsaw, Poland \\ ${ }^{\mathrm{d}}$ Geological Institute, Copenhagen University, Copenhagen, Denmark
}

\begin{abstract}
We discuss the structure of the continental lithosphere, its physical properties, and the mechanisms that formed and modified it since the early Archean. The structure of the upper mantle and the crust is derived primarily from global and regional seismic tomography studies of Eurasia and from global and regional data on seismic anisotropy. These data as documented in the papers of this special issue of Tectonophysics are used to illustrate the role of different tectonic processes in the lithospheric evolution since Archean to present. These include, but are not limited to, cratonization, terrane accretion and collision, continental rifting (both passive and active), subduction, and lithospheric basal erosion due to a relative motion of cratonic keels and the convective mantle. (C) 2002 Elsevier Science B.V. All rights reserved.
\end{abstract}

Keywords: Lithosphere; Crust; Mantle

\section{Introduction}

The determination of the structure and composition of the lithosphere has challenged geologists and geophysicists for decades. Initial work defined the mechanical properties of the lithosphere, while recent studies have measured many other physical parameters. Key characteristics such as anisotropy, scattering, discontinuities and low-velocity zones (LVZs) within the lithosphere of cold cratonic regions are still much debated.

This special issue of Tectonophysics is devoted primarily to discussions of the structure of the con-

\footnotetext{
* Corresponding author.

E-mail address: irina.artemieva@eost.u-strasbg.fr (I.M. Artemieva).
}

tinental lithosphere, its physical properties, and the mechanisms that have formed and modified it. The volume is a result of discussion at two symposia (SE17 and SE18) at the European Geophysical Society (EGS) Annual Meeting in 2000 in Nice. Contributions at these symposia included global and regional tomographic studies, seismic imaging of lithospheric discontinuities, studies of seismic anisotropy in the crust and the upper mantle, investigations of the thermal state of the lithosphere, and analyses of the Earth's gravity field.

The papers presented in this volume provide the reader with a meaningful perspective into this fascinating branch of Earth Science. Their main focus and contributions are outlined below and the regions discussed are shown in Fig. 1. Six of the 12 papers comprising the volume cover global and regional seismic 
tomography studies, including P- and S-wave velocities, with the focus on the structure of the upper mantle in areas of Eurasia and of the continental rifts. The interpretation of seismic anisotropy within the crust and upper mantle has become a leading topic over the past 10 years. Four of the papers presented in this volume provide further evidence for the pervasive role played by this important physical property. Two papers in the volume focus on seismic imaging of lithospheric discontinuities and present a global overview of the processes of possible lithosphere basal erosion.

The results reported in these 12 papers provide the basis for a refined understanding of the structure of the continental crust and uppermost mantle as well as processes of the evolution of the continental lithosphere, such as cratonization, accretion, rifting, collision, subduction, and back-arc spreading. Here we present a brief discussion of the role of these processes in the lithosphere evolution as documented by new results reported in this volume.

\section{Lithosphere of Archean Cratons: its formation, structure, and role in plate motion}

The age of the oldest continental lithosphere (e.g., Siberian craton, South Africa, and Western Australia) is $>3.0 \mathrm{Ga}$, as revealed by studies of $\mathrm{Sm}-\mathrm{Nd}$ and $\mathrm{Re}-$ Os isotopes in diamond inclusions - the minerals that do not recrystallize during later tectonic events and thus provide the original age of the subcrustal lithosphere down to a depth of $>200 \mathrm{~km}$ (e.g. Richardson et al., 1993; Carlson et al., 1994). As argued by Condie (1997), it is not clear if the model ages record the formation time of the continental lithosphere or rather the age of metasomatic events associated with cratonization. However, petrological studies of xenoliths from kimberlite pipes of South Africa (Pearson, 1999) indicate that the entire lithospheric column of the cratonic keel down to depths of at least 220-250 $\mathrm{km}$ was formed during a relatively short time interval by a fast tectono-magmatic event, rather than by gradual addition of new lithospheric material to the lithospheric base over a long period of time. Moreover, isotopic ages indicate that the mantle lithosphere of the cratons and the overlying crust were formed at the same time and since then remained attached (Carlson et al., 1994; Pearson et al., 1995).
A chemically distinct composition of the Archean lithosphere, which is depleted in $\mathrm{Ti}$ and $\mathrm{Ca}$ and has high $\mathrm{Mg} / \mathrm{Fe}$ ratio (e.g. Boyd, 1989), suggests that it formed under unique conditions, which did not exist in the post-Archean time. Campbell and Griffiths (1992) argue that basal plume accretion could have been important for the formation of the oldest Archean continental nuclei (Fig. 2A). For example, $\mathrm{Re}-\mathrm{Os}$ isotope studies of the lithospheric mantle at Lac de Gras, Slave Craton, suggest that the deepest part of the lithosphere was derived from the lower mantle by plume subcretion at $3.4-3.3 \mathrm{Ga}$ (Aulbach et al., 2001). Very deep melting (10-20 GPa) in the early Archean plumes (Herzberg, 1995) and high mantle temperatures (Abbott et al., 1994) could have produced a high degree of melting in the rising magma $(>30 \%)$ to form thick lithospheric keels, as suggested by the abundance of Archean greenstones.

At present, the Precambrian lithosphere commonly has a unique thickness, perhaps almost reaching the $410-\mathrm{km}$ discontinuity beneath some of the Archean cratons, as indicated by global seismic tomography and thermal models (e.g. Zhang and Tanimoto, 1993; Grand, 1994; Artemieva and Mooney, 2001). Artemieva and Mooney (this volume) postulate that an early Archean supercontinent could have had 450-kmthick lithosphere and present a global summary of the present-day lithospheric thickness, with particular reference to the continental cratons (Fig. 1). Their analysis indicates that the horizontal and vertical dimensions of the cratons are correlated, so that larger cratons have thicker lithosphere.

Regional seismic tomography studies support the existence of very thick $(\sim 300 \mathrm{~km})$ lithospheric keels beneath the Precambrian cratons (Ritsema and van Heijst, 2000; Simons et al., 1999). In this volume, Bushenkova et al. present the results of recent tomography studies of the upper mantle structure in central Siberia (which includes the Archean to early Proterozoic Siberian craton and the Paleozoic West Siberian Basin), based on a new method of seismic inversion. This method, called the RR-R scheme, uses teleseismic P- and S-wave arrivals in combination with their corresponding PP or SS arrivals that have surface reflection points in the study region. This method has the advantage that it can be used in areas with no stations or earthquakes. The results of the inversion show several interesting features of lithospheric struc- 


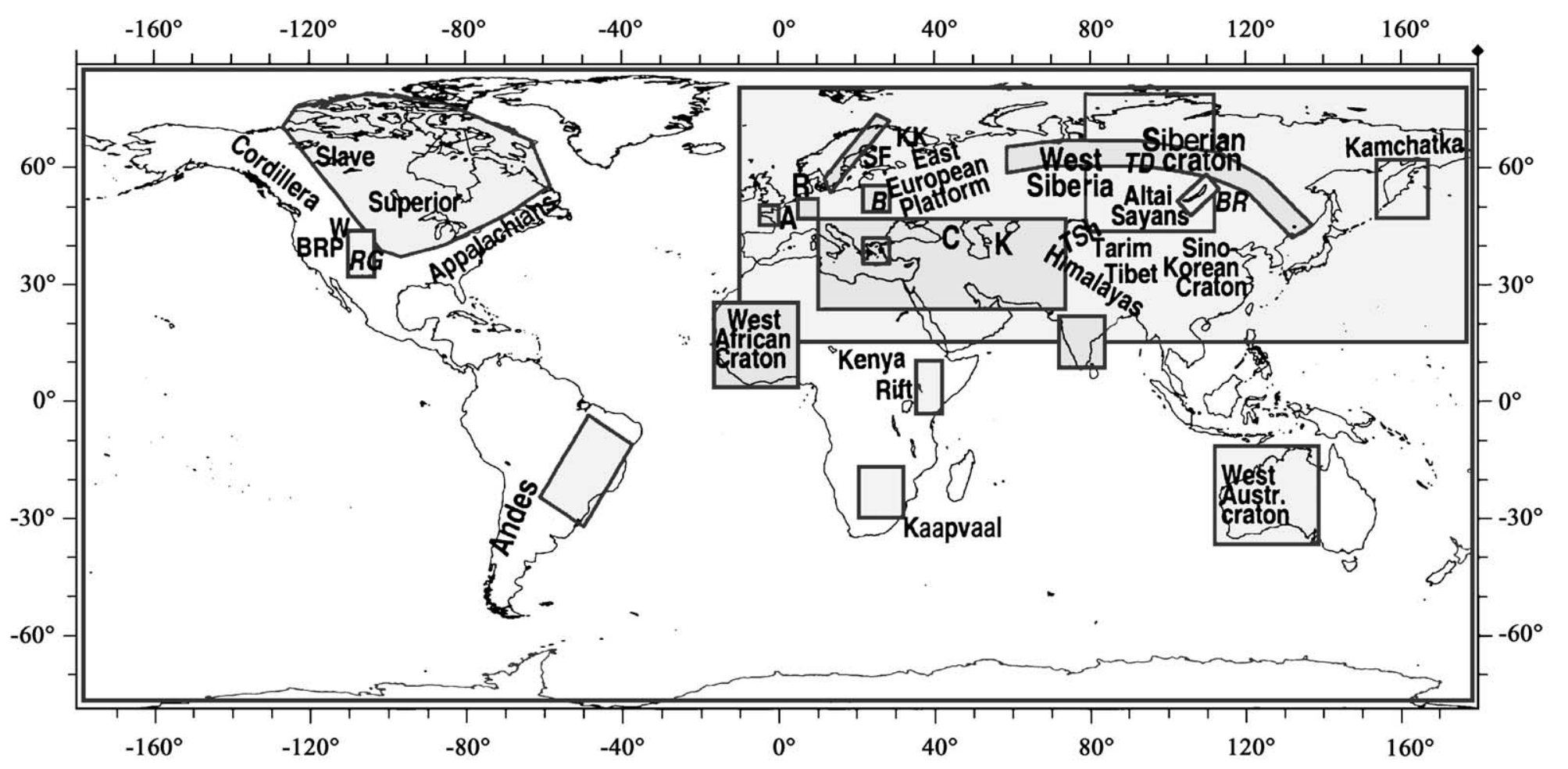

Fig. 1. Regions discussed in this paper and in this volume. Boxes show the specific areas of investigations. Abbreviations: A-Armorican Massif; B-the Belarus Belt; BR-Baikal Rift; BRP—Basin and Range Province; C—Caucasus; K—Kopet-Dagh; KK—Kola-Karelian Province of the Baltic Shield; R—Rhine Graben; RG-Rio Grande Rift; SF-SvecoFennian Province of the Baltic Shield; TD—Tunguska depression; TSh-Tien Shan; W-Wyoming Craton. 
ture in Siberia. In particular, positive seismic velocity anomalies $(\sim 1 \%)$ down to a depth of $\sim 350 \mathrm{~km}$ are associated with the Archean-early Proterozoic Siberian craton. Thinner lithosphere $(\sim 300 \mathrm{~km})$ is estimated for the Precambrian Tunguss depression. Negative relative velocity anomalies are found in the thin lithosphere of the Paleozoic West Siberian basin, but can be partly attributed to poor vertical resolution of the model. However, it is possible that PermoTriassic back-arc extension in the West Siberian Basin (Kusznir and Ziegler, 1992) was associated with passive upper mantle upwelling.

The question of how thick lithospheric keels could have survived since the Precambrian is addressed by Artemieva and Mooney (this volume), who analyze the basal drag model of lithospheric erosion. They investigate the hypothesis that plate motion influences the structure of deep lithospheric keels by examining the correlation between thickness of Precambrian continental lithosphere and plate velocity. The analysis shows that plates with thicker Archean keels move slower. The deepest, Archean, part of the lithospheric keels, extending below the LVZ to depths of 200-350 $\mathrm{km}$ resists plate motion and is affected by basal erosion. Basal drag may have varied in magnitude over the past $4 \mathrm{Ga}$ because high mantle temperatures in the Archean would have resulted in low mantle viscosity. This in turn would have reduced basal drag and basal erosion, and promoted the preservation of thick $(>300 \mathrm{~km})$ Archean keels, even if plate velocities were high during the Archean. However, Stoddard and Abbott (1996) argue that, on the contrary, the Proterozoic part of the cratonic lithospheric keels assists plate motion, if located within seismic lowvelocity (and low-viscosity) zone in the upper mantle.

The structure and the very existence of this LVZ in the cold upper mantle beneath the Precambrian cratons is a subject of debate. Models of isostatic postglacial rebounds in northeastern Canada and Fennoscandia imply that a low-viscosity layer may be present in the upper mantle beneath the cratons (e.g. Peltier, 1974). Some models based on inversion of relative sea-level changes require a low-viscosity asthenosphere only in the peripheral parts of Fennoscandia, but not beneath the cratonic part (Kaufmann and $\mathrm{Wu}, 2002)$. However, models of depth-distribution of mantle viscosity are strongly dependent on the assumed lithospheric structure, which typically includes a low-viscosity zone extending from the base of the elastic lithosphere to the $660-\mathrm{km}$ discontinuity (e.g. Lambeck et al., 1998); these models may not accurately resolve both the depth range of the lowviscosity layer and the amplitude of the viscosity anomaly, but instead evaluate their integrated effect.

Seismic and seismological evidence for the existence of the LVZ in the Earth's mantle below a depth of ca. $100 \mathrm{~km}$ has been found in many regional studies, for example, in North America and Europe (Burdick, 1981; Zielhuis and Nolet, 1994), the Siberian Craton (Nielsen et al., 1999), and Tibet (Romanowicz, 1982; Zeng et al., 1995). Anderson (1989) mentions that "the pronounced minimum in the group velocity of long-period mantle Rayleigh waves is one of the classical arguments for the presence of an upper-mantle low-velocity zone". In the fifties, the LVZ was believed by seismologists to be a global feature. In discussions of the $20^{\circ}(400 \mathrm{~km})$ discontinuity, Gutenberg (1954) proposed "a shadow zone caused by a low velocity zone centered at $100-150$ $\mathrm{km}$ depth". In subsequent studies, however, much of the attention has been shifted to the major, deeper discontinuities at the mantle transition region, and studies of the LVZ in the uppermost mantle became less popular, partly because of uncertainties in its detection.

The base of the LVZ, the Lehmann discontinuity, was first interpreted from earthquake data beneath Europe and from GNOME nuclear explosion data beneath the North American craton and was found to be at ca. $220 \mathrm{~km}$ depth (Lehmann, 1961, 1962). However, the existence of a seismic discontinuity at this depth had already been proposed by Galitzin in 1917. For several years, the Lehmann discontinuity was considered to be a global boundary at $\sim 200 \mathrm{~km}$ depth until it was suggested that it is a local feature, which is observed under oceans twice less often than in cratonic areas (e.g. Gu et al., 2001). Recent interpretations of the nature of the Lehmann discontinuity include an abrupt change in anisotropy of the mantle rocks (Gaherty and Jordan, 1995) or the base of the zone of partial melting within stable continental lithosphere (Lambert and Wyllie, 1970; Hales, 1991; Thybo and Perchuc, 1997).

Xenolith studies (e.g. Boyd and Gurney, 1986; Griffin et al., 1999) and global thermal modeling (Artemieva and Mooney, 2001) indicate that the 
bottom of the LVZ at a depth of $\sim 175-185 \mathrm{~km}$ coincides with the maximal depth extent of the middle to late Proterozoic part of cratonic lithospheric roots. Commonly, this depth is also the minimal thickness of Archean lithosphere, which has not been reworked or metasomatised by later tectonic events. Thus, seismic models with the LVZ in the upper mantle beneath Precambrian cratons support a hypothesis of Stoddard and Abbott (1996) that the Proterozoic part of lithospheric keels, typically positioned within the depth interval of $120-180 \mathrm{~km}$, is likely to assist the plate motion as it is located within a rheologically weak part of the upper mantle.

Two papers in this volume address the structure of the LVZ in the upper mantle, examining seismic data for the platform areas of Eurasia. Abramovitz et al. (this volume) use tomographic inversion of $\mathrm{P}$ - and $\mathrm{S}$ wave velocities to determine the structure of the upper mantle of the Baltic shield along the long-range deep seismic sounding profile FENNOLORA. The authors attribute observed pronounced scattering and delay in travel times of seismic P- and S-wave phases together with strong attenuation of S-wave phases beyond $\sim 800 \mathrm{~km}$ offset to a LVZ at a depth below $\sim 100$ $\mathrm{km}$. No refracted S-wave phases are observed beyond $1200 \mathrm{~km}$ offset, which is attributed to strong S-wave attenuation within the zone below $\sim 100 \mathrm{~km}$ depth. The authors interpret these features as indications of the presence of rocks close to the melting point, or small amounts of partial melts, or possibly free fluids, in the 100- to $150-\mathrm{km}$-depth interval.

Nielsen et al. (this volume) come to similar conclusions in their study of the lithosphere of Eurasia by modeling seismic scattering along the 3500-km-long Peaceful Nuclear Explosion (PNE) profile Kraton (Fig. 1). Their preferred seismic velocity model includes random velocity fluctuations with horizontal scale of $5-10 \mathrm{~km}$, thickness less than $5 \mathrm{~km}$, and standard deviation of $2 \%$ from background velocity. It agrees with an upper mantle model in which an inhomogeneous low-velocity scattering layer at depths of between 100 and $185 \mathrm{~km}$ may contain small amounts of partially molten material. Alternatively, the authors suggest that the combined effects of rheological weakening and small-scale anisotropy may also account for the low-velocity scattering layer (with an observed $\sim 1 \%$ velocity reduction compared to layers above and below it).

\section{Precambrian plate tectonics: lithosphere growth by accretion and subduction}

Recent LITHOPROBE seismic reflection studies across the Archean Superior Province and western margin of the Canadian Shield (e.g. Clowes et al., 1998; Cook et al, 1999) indicate that plate tectonics operated already in the early Archean (Calvert et al., 1995; Condie, 1997; Aulbach et al., 2001), though probably in a somewhat different way than today (Bailey, 1999). However, structures formed during early to middle Proterozoic collision appear similar to the present-day tectonics (BABEL Working Group, 1990). The oldest known accretionary orogens, documented by petrotectonic assemblages, are $4.0-3.9 \mathrm{Ga}$ old (in northwestern Canada and southwestern Greenland), whereas the oldest collisional orogens are of the early Proterozoic age (in northwestern Canada and Western Australia). Zones of relict subduction are revealed by seismic reflection studies in other continental regions; for example, pre-Caledonian oceanic subduction is evident in bright continuous seismic reflectors within the lower part of Precambrian lithosphere offshore north of Scotland (Warner et al., 1996).

Subduction provides an efficient mechanism of lithosphere destruction and recycling within the mantle. Besides, it implies that mechanisms other than basal lithospheric accretion by mantle plumes were responsible for the formation of the submarine plateaux of the early continental lithosphere. These include underplating of buoyantly subducted slabs around the perimeters of pre-existing lithospheric fragments (Fig. 2C) and collision of oceanic terranes (such as submarine plateaux and island arcs) (Fig. 2B) with pre-existing continental margins (Abbott and Mooney, 1995; Rudnick, 1995). Both of these processes would contribute to lateral growth of the continental nuclei and lithospheric thickening.

The well-preserved Kaapvaal craton of South Africa provides evidence that continental fragments were amalgamated in the Archean by processes similar to the modern plate tectonics (De Wit et al., 1992). Two papers in this volume on seismic and gravity studies of the Baltic Shield and the western part of the East European Platform provide support for the hypothesis of Percival and Williams (1989) that accretion of oceanic terranes could have been an important global process of continental lithosphere 


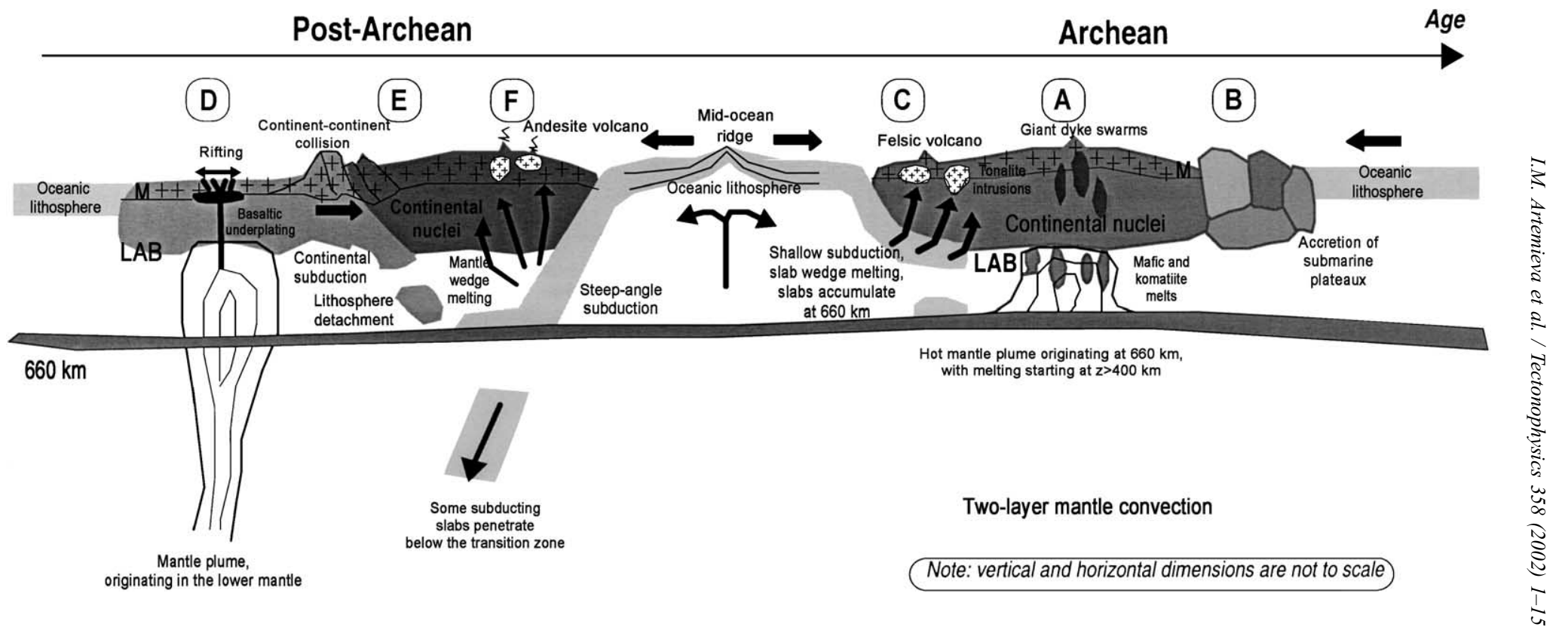

Fig. 2. Major processes of lithosphere formation and modification in Archean and post-Archean time. Early continental lithosphere (right) (with the focus on processes characteristic of the Archean). (A) Assembly of continental nuclei above hot mantle plumes, originating from a depth of $660 \mathrm{~km}$, and generation of first giant dyke swarms. (B) Growth of an Archean craton by the accretion of submarine plateaux. (C) Growth of Archean continental crust by melting within the slab wedge during buoyant subduction. Post-Archean (left) (with the focus on processes that did not operate during the Archean). (D) Rifting and basalt underplating caused by lower mantle plumes. (E) Collisional orogens, continental subduction and lithosphere detachment. (F) Crustal growth by melting in the mantle wedge during steep subduction. Some subducted slabs sink into the lower mantle. $\mathrm{LAB}=$ lithosphere - asthenosphere boundary; $\mathrm{M}=$ crustal base 
growth in the Precambrian (EUROBRIDGE Seismic Working Group, 1999).

Kozlovskaya et al. (this volume) combine seismic anisotropy and gravity in an integrated study of the deep structure of the crust in the Belarus Belt (which is a part of one of the fundamental sutures within the East European Craton) (Fig. 1) along the EUROBRIDGE'96 seismic refraction profile. Based on the seismic structure, this paper documents evidence for two sub-terranes within a 2.0- to 1.9-Ga Paleoproterozoic terrane with contrasting metamorphic and magmatic histories. The suture between the sub-terranes is believed to mark a zone along which the SE subterrane was stacked and compressed during late Archean $(1.95-1.8 \mathrm{Ga})$ subduction of oceanic crust beneath the Sarmatia protocontinent (Taran and Bogdanova, 2001). Seismic anisotropy in the middle crust of these sub-terranes is proposed to explain a high Pwave velocity anomaly that does not correspond to a positive gravity anomaly.

Abramovitz et al. (this volume) analyze lateral variations in the $V_{\mathrm{p}} / V_{\mathrm{s}}$ ratio of the crust and uppermost mantle of the Baltic Shield along the FENNOLORA profile (Fig. 1) and correlate them with Proterozoic terranes, which collided and were amalgamated during the Precambrian plate tectonic events that led to the assemblage of the Baltic shield. The largest $V_{\mathrm{p}} / V_{\mathrm{s}}$ contrasts are observed at the boundaries between terranes of different ages, that is, (a) between the Kola-Karelian and Sveco-Fennian provinces and (b) between the Sveco-Fennian province and the TransScandinavian Igneous belt. A recent theoretical study (Takei, 2002) shows that the $V_{\mathrm{p}} / V_{\mathrm{s}}$ ratio is sensitive not only to the presence of fluids and melts, but also to the pore geometry. Thus, $V_{\mathrm{p}} / V_{\mathrm{s}}$ variations in the crust can be indicative of a different rock texture in crustal terranes.

An important question is the geometry of the transition between terranes of different ages, as it permits us to speculate on the tectonic processes by which they were amalgamated. The results of Abramovitz et al. (this volume) show that in the Baltic Shield, the boundaries between the Precambrian terranes are not vertical, for example the Proterozoic Sveco-Fennian province underlies the NW part of the Archean Kola-Karelian block. A dipping structure, resembling modern subduction, was imaged in deep seismic reflection profiles in the northern Baltic
Shield at one of the terrane boundaries by the BABEL Working Group (1990). Seismic reflection studies at the Lac de Gras area of the western Canadian Shield (Cook et al., 1999) indicate that the Central Slave basement complex (>3.4 Ga) underlies the 2.7-Ga-old crust of the arc-accreted Contwoyto terranes, which was interpreted by Aulbach et al. (2001) as evidence for Precambrian $(\sim 2.8 \mathrm{Ga})$ subduction. Thus, the results of seismic studies in North America and Eurasia suggest that subduction and terrane accretion were worldwide phenomena already in the Archeanearly Proterozoic time.

\section{Phanerozoic plate tectonics: collisional orogens and subduction beneath Eurasia}

Seismic tomography studies, pioneered by the works of Aki et al. (1977), Dziewonski (1984), and Woodhouse and Dziewonski (1984) show structures that strikingly resemble predictions from models of large-scale mantle processes, including the accretion of terranes, rifting, and continent-continent or continent-ocean collision (indicated by elongated highvelocity anomalies) (Fig. 2, D-F). Global wholemantle tomography models (for a recent review, see Montagner, 1994) reveal correlations between the structure of the upper mantle and plate tectonics. These results stimulated regional tomography studies, which potentially may link the present-day mantle velocity structure to past tectonic events.

Reconstruction of the location of paleo-subduction zones provides independent constraints for paleogeography (e.g. Bunge and Grand, 2000) and for mantle convection models (e.g. Chase and Sprowl, 1983). Recent high-resolution P-wave and S-wave tomography studies of the circum-Pacific subduction zones (for a detailed review, see Fukao et al., 2001) indicate that most of the subducted slabs are deflected near the 660$\mathrm{km}$ discontinuity, in support of the hypothesis of subhorizontal flow in the mantle transition zone. However, some positive seismic velocity anomalies that may relate to subducting slabs reach deeper into the lower mantle (Fig. 2F) (Van der Hilst et al., 1997). This result has important implications for mantle convection models (whole-mantle, layered, or hybrid) and supports the idea of episodic catastrophic overturns in the mantle (e.g. Condie, 1998), associated with sinking 
of the slabs to a compositionally heterogeneous layer at 1700-2300 km depth (Van der Hilst and Karason, 1999 ) or to the core-mantle boundary, which in turn could initiate large mantle plumes (Davies, 1995).

Ancient subduction zones have been imaged beneath several continents; at present, many of them are located very far from the continental margins. For example, a pronounced velocity anomaly that may be correlated with the Farallon slab beneath North America is clearly seen in a regional S-wave model at a distance of $\sim 2000 \mathrm{~km}$ from the present Pacific margin (Van der Lee and Nolet, 1997). Besides typical oceanic subduction zones, continental subduction zones can develop in regions of strong compressional tectonics (Fig. 2E). Van der Voo et al. (1999b) present a tomographic cross section of the subduction region of the Indo-Australian plate beneath the Himalayas. Besides this well-known subduction zone in Eurasia, another fast seismic velocity anomaly at depths below $1500 \mathrm{~km}$ beneath Siberia (Bjiwaard et al., 1998) was interpreted as a paleo-subducted slab (Van der Voo et al., 1999a).

The present volume includes several papers on tomographic studies of the collisional orogens in Eurasia and of ancient subduction zones. Judenherc et al. (this volume) provide an example of Phanerozoic continental growth in Europe. They study lithospheric heterogeneities in the Hercynian Range in western France, which was formed during the collision of Gondwana and Laurasia (250-400 Ma). The authors seek answers to the questions: Does the lithosphere beneath the old orogens keep the signature of past geodynamic events? Do the tectonic features extend through the whole lithosphere? The authors present a 3-D P-wave velocity model of the Armorican Massif (Fig. 1) down to $\sim 150 \mathrm{~km}$ depth and a map of S-wave seismic anisotropy at depth from teleseismic S-wave splitting measurements. They find that the lithosphere beneath the Hercynian range consists of two seismologically distinct domains. High (4-5\%) P-wave velocity anomaly and a strike-parallel fast S-wave velocity characterize the South-Armorican lithosphere, whereas the North-Amorican lithosphere has lower velocity and does not show sign of any significant anisotropy. The authors attribute $1-2 \%$ of the velocity difference at depths below $90 \mathrm{~km}$ to a compositional difference between the South-Armorican and the North-Armorican lithospheric domains. The tomographic image and the seismic anisotropy data suggest that the Armorican lithosphere consists of juxtaposed distinct lithospheric blocks, which were assembled in a collision-related subduction-type process that predated the Hercynian orogeny.

Geological and geophysical evidence indicates that Phanerozoic plate tectonic processes are similar to those that operated in the Precambrian. The Cordilleran and Appalachian orogens in North America are Phanerozoic examples of collisional growth of a continent by accretion of oceanic terranes at convergent plate boundaries (Condie and Chomiak, 1996). Recent studies using seismic reflection and refraction methods together with receiver functions have revealed details of the subducting oceanic slab under the South American continent and indicated the role of the subduction process in the formation of the Andean orogen (ANCORP Working Group, 1999). Metamorphic processes are found to have strong influence on the seismic reflection properties of the subducting slab and, surprisingly, also on the location of major earthquakes, which are concentrated within the slab but not at its upper boundary (Yuan et al., 2000).

Bushenkova et al. (this volume) observe a mosaic pattern of velocity anomalies in the Altai-Sayan region of Central Asia (Fig. 1). High-velocity anomalies are interpreted as either thick, cold cratonic lithosphere or cold sinking lithospheric slabs; low-velocity anomalies are correlated with either thin lithosphere or mantle upwellings, for example, in continental rift zones. A NW-SE trend of velocity anomalies in Central Asia corresponds to the orientation of the terranes accreted to the Siberian craton in the Paleozoic (late Devonian) (Molnar and Tapponnier, 1975; Sengör et al., 1993).

Koulakov et al. (this volume) focus their tomographic studies on the structure and dynamics of the upper mantle beneath the Alpine-Himalayan orogenic belt at depths between 100 and $500 \mathrm{~km}$. The tomographic maps show pronounced traces of subducted slabs in the regions of Hellenides, the Cretan arc, the Hindukush, and Burma, where past subduction is confirmed by independent data. In other regions they find similar, but less-certain, evidence of subduction; for example, positive anomalies in the western part of the Alpine-Himalayan orogenic belt are attributed to subduction in the area of Cyprus and along the Caucasus-Kopet-Dagh-Lut plate.

Recent seismic studies in the Himalayan-Tibetian area have provided evidence for subduction of the 
continental lithosphere of the Indian plate under the Asian plate (Kosarev et al., 1999). Together with the results of controlled source seismology (Nelson et al., 1996), evidence is found for extensive melting of the upper crust beneath the Tibetian plateau. The tomographic maps of Koulakov et al. (this volume) show velocity anomalies indicative of the subducted Indian slab under the western Himalayas. Beneath the eastern Himalayas, low seismic velocities in the upper mantle indicate high temperatures. Zones of sinking lithosphere (subduction) are likewise traceable around the Tarim block in Central Asia. In agreement with Bushenkova et al. (this volume), Koulakov et al. (this volume) note that a strong small-size low-velocity anomaly in Mongolia is apparently related to the Hangai plume, which has been inferred from other geological and geophysical evidence. However, recent gravity modeling (Petit et al., 2002) shows that dome topography and xenolith data can be fitted by a low-density $600-\mathrm{km}$-wide body at a depth of $100-200 \mathrm{~km}$, which may not be associated with a mantle plume.

Ritzwoller et al. (this volume) present results of a seismic tomography study of Eurasia motivated by a wish to improve the location of regional seismic events. They map Pn and Sn velocities beneath most of Eurasia, thereby revealing structural information at a length scale relevant to regional tectonics; the result has also provided an evaluation of recently constructed 3-D mantle models. The authors developed and tested a method to produce Pn and Sn travel time correction surfaces that are the 3-D analogues of travel time curves for a 1-D model. The most intriguing features on the Pn and Sn maps of Eurasia are the lowvelocity anomalies that characterize most tectonically deformed regions. One such anomalous zone exists across southern Asia and the Middle East, extending from Turkey in the west to Lake Baikal in the east. These anomalies are almost certainly related to the closure of the Neo-Tethys Ocean and the collision of India with Asia. Low-velocity anomalies beneath the Pacific margin, the Red Sea rift, the Tyrrhenian Sea, and other regions undergoing active extension are likely to be associated with back-arc spreading. No conclusions can be made for most of the shield and platform regions of Eurasia (the East European Platform, the West Siberian Basin, and the Siberian Craton), where the ray coverage is very poor.
The seismic tomography results of Koulakov et al. and Ritzwoller et al. (this volume) outline zones of past subduction beneath the Mediterranean region, the Alpine-Himalayan zone, and Central Asia. The location of these seismic anomalies in the upper mantle correlates with globally reconstructed subduction zones for the past $200 \mathrm{Ma}$, based on a compilation of finite plate rotations (Richards and Engebretson, 1992). The latter study implies that subduction along convergent boundaries has been active in the Himalayan zone for the past $\sim 120 \mathrm{Ma}$, across the Middle East, Arabia and southern Asia for the past $\sim 90 \mathrm{Ma}$, and in the Mediterranean region for the past $\sim 60 \mathrm{Ma}$.

\section{Break-up of continental lithosphere: role of mantle plumes in rifting}

Deep mantle processes lead to episodic continental growth and formation of super-continents, as reflected in episodic age distributions of granitoids and greenstone belts (e.g. McLennan and Taylor, 1985; Condie, 1998) that correlate with the ages of large igneous provinces and giant dyke swarms (Yale and Carpenter, 1998). The super-continents are split and dispersed by continental rifting (Fig. 2D). Modern continental rifts provide unique opportunities to study the initial stages of continental break-up, as for example, in the Afar Triangle in Ethiopia. The oldest known continental rifting event $(\sim 3.0 \mathrm{Ga})$ is documented by petrotectonic assemblages in the Kaapvaal craton; another Precambrian example is the Keweenawan rift in the north-central USA. Ancient giant mafic dyke swarms (the oldest, the Ameralik swarm in southwestern Greenland, is $\sim 3.25 \mathrm{Ga}$ ) indicate that plume-lithosphere interaction played an important role in the evolution of the continental lithosphere since its very formation. The Wyoming craton in North America and the Sino-Korean craton in China are examples of lithospheric keels, that were eroded and metasomatised during large-scale lithosphere-mantle interaction, which may have its origin in mantle plumes (e.g. Eggler et al., 1988; Griffin et al., 1998, 1999).

Geodynamic models of the formation of continental rifts and large extensional structures can be divided into the "active" and "passive" models, as defined by Sengör and Burke (1978). The models of active rifting suggest that crustal extension and associated rifting is 
driven by thermal perturbations in the mantle (Bott, 1995). This results in ascent of hot mantle material to shallow depths (in some cases to the base of the crust) and subsequent lithospheric extension and thinning. How deep in the mantle are the driving forces of active rifting? Continental rifts appear to have two source depths: the upper mantle and the core-mantle boundary. In the latter case, large-scale rifts result from plumes that are rooted at the core-mantle boundary (e.g. Loper and Stacey, 1983). However, little direct evidence exists so far for plumes beneath the continental rifts, their presence being chiefly hypothesized from large volumes of magmatic rocks associated with the rifting process. An upper mantle source of rifting is often associated with convection in the upper mantle, that is, above the $660-\mathrm{km}$ discontinuity, or with secondary convection (e.g. Griffiths and Campbell, 1991). In this case, continents form a thermal blanket that allows the underlying mantle to heat up, thereby leading to uplift and eventually rifting.

The passive models imply that the primary mechanism of continental rifting is lithospheric extension caused by deviatoric stresses in the lithosphere produced by plate boundary forces. If the deviatoric tension is large enough and/or the lithosphere is relatively thin and hot, it can cause lithospheric failure (Kuznir and Park, 1984) accompanied by passive ascent of hot mantle material into the weak zones of the lithosphere. In this hypothesis, neither the upper nor the lower mantle plays an important role as a driving force for the rifting process. However, the upper mantle provides the melt for volcanism that is associated with extension and rifting. Thus, the passive rifting model is difficult to distinguish from the secondary convection model. The debates on the passive or active origin of different continental rifts still continue.

Achauer and Masson (this volume) evaluate tomographic images of the four major recent continental rift zones (the Kenya, Baikal, and Rio Grande rifts and the Rhine Graben) (Fig. 1) by comparing absolute velocity models, derived from recent global 3-D surface wave tomography. The four rifts differ substantially down to depths of $\sim 300 \mathrm{~km}$. The results indicate that the Kenya and the Rio Grande rifts may be considered as active rifts where large upwelling plumes control their evolution, whereas the southern Rhine Graben and the Baikal Rift zone are more likely to be passive rifts.
Earlier long-range seismic refraction and teleseismic studies of the East African and Rio Grande rifts provide compelling evidence for a hot mantle down to depths of at least $100-200 \mathrm{~km}$ and support the hypothesis of an active, deep mantle, origin (Braile et al., 1995; Baldridge et al., 1995). The recent tomography models by Koulakov et al. (this volume) show positive relative velocity anomalies beneath the Baikal rift zone in the depth range $100-500 \mathrm{~km}$ and thus support the conclusion of its passive origin.

The Basin and Range Province in western USA is another example of passive lithosphere extension (Parsons, 1995). The model of adiabatic melting of mantle material due to lithosphere extension (McKenzie and Bickle, 1988) predicts basaltic magma generation in tectonically active areas only in highly extended regions; for realistic lithosphere thickness and mantle temperature, lithosphere extension must be larger than $100 \%$ to initiate melting of a peridotitic mantle. Such values of extension are typical for the Northern Basin and Range Province, where they are about $200-250 \%$ on average and have even higher local values (Gans, 1987). Achauer and Masson (this volume) conclude that complex regional and far-field stresses (caused by plate motion) as well as the rheological strength of the lithosphere (determined by its tectonic history) govern the evolution of rifts, which tend to follow the pre-existing inherited structures and zones of rheological or tectonic weakness.

\section{Recent plate tectonics and anisotropy}

Whereas seismic anisotropy has long been known within the Earth's mantle (Anderson, 1961), there has been increasing recognition that the metamorphic rocks within the crust can possess as much as $10-$ $15 \%$ seismic anisotropy. In the mantle, elastic anisotropy is commonly attributed to the preferred orientation of olivine crystals (e.g. Karato, 1992). Thus, the total measured anisotropy is a combination of crustal and mantle components, which generally will have different orientations (e.g. Christensen et al., 2001). Savage (1999) reviews in detail recent progress on seismic anisotropy studies.

The observation of shear-wave splitting on broadband seismic waveforms has led to two competing models for anisotropy within the upper mantle. Vinnik 
et al. (1998, 1999) argue for anisotropy primarily within the asthenosphere based on the agreement between plate motion directions and the orientation of the fast axis of wave speed. Such correlations were found in most oceanic regions at $100-200 \mathrm{~km}$ depth (e.g. Nishimura and Forsyth, 1989; Montagner and Tanimoto, 1991; Lévêque et al., 1998). Silver and Chan $(1988,1991)$ argue for anisotropy primarily within the lithosphere ("frozen-in anisotropy") based on agreement between the geometry of continental accretion and the orientation of the fast axis. Similarly to continents, anisotropy in the lithosphere beneath oceans is commonly assumed to be frozen-in and associated with the spreading direction (e.g. Nishimura and Forsyth, 1989).

These two points of view need not be incompatible. As argued in this volume, seismic observations are best modeled by a combination of lithospheric and asthenospheric anisotropy. This view is strongly supported by the results of Plomerova et al. (this volume) and Lévêque et al. (1998) from changes in the depthdistribution of the radial and azimuthal surface-wave anisotropy. The results of the later study imply that below the Australian continent, the drastic change in the direction of anisotropy occurs at a depth of 150$200 \mathrm{~km}$, while a positive velocity anomaly is clearly seen down to $\sim 300 \mathrm{~km}$ depth. Similar results were reported for the South African craton by Vinnik et al. (1995), who have proposed that the deep part of continental roots (below $\sim 200 \mathrm{~km}$ depth) can experience deformation associated with plate motion and mantle flow.

Plomerova et al. (this volume) propose a global model of lithospheric thickness, wherein the lithosphere-asthenosphere boundary (LAB) is considered to be the transition between 'frozen-in' anisotropy in the lithosphere and mantle flow-related anisotropy in the asthenosphere. These two anisotropic zones can have different alignments of mantle olivine, and the authors interpret a depth where a change in the direction of anisotropy occurs as the LAB. Depths to the $\mathrm{LAB}$ are estimated to be between 200 and $250 \mathrm{~km}$ beneath Precambrian shields and platforms, around $100 \mathrm{~km}$ in the Phanerozoic continental regions, and $40-70 \mathrm{~km}$ beneath oceans. From changes in the depthdistribution of anisotropy, the lithospheric thickness surprisingly exceeds $200 \mathrm{~km}$ beneath the Caucasus Himalayas - Tien Shan - Tibet mountain belt. How- ever, another interpretation of the observed anisotropy in this Cenozoic orogenic belt may be in terms of "escape tectonics" and associated anisotropy in a rheologically weak lower crust and subcrustal lithosphere (Meissner et al., 2002). A global study of Smith and Ëkstrom (1999) supports the idea that beneath the continents, anisotropy commonly reflects the most recent deformation event.

Seismic anisotropy, which is sensitive to deformation of the mantle rocks, provides an image of the mantle flow associated with thermal convection and plate motions. For example, simple shear flow from convection would produce alignment of olivine crystals along the flow direction. The relationship of upper-mantle anisotropy to past and present plate motion is discussed in a recent review of Park and Levin (2002), who state that seismic anisotropy is not only a result of past processes now frozen into the lithosphere, but it is also a result of active processes. This hypothesis holds the promise that seismic anisotropy may be used to determine the role of the mantle in active processes such as plate motions, crustal deformation in collision zones, and vertical crustal movement that form both stable platforms and broad uplifts. Seismic anisotropy studies of subduction zones (starting with the works of Ando et al., 1983; Fukao, 1984) provide new insights into active processes in the mantle. In the present volume, two papers address slab anisotropy.

Levin et al. (this volume) document the existence of anisotropy within a supra-slab asthenospheric mantle wedge from an investigation of the crust and upper mantle structure of Kamchatka, far-eastern Russia (Fig. 1), by teleseismic receiver functions. This experiment reveals regional variations in the Moho depth (30-40 km across the peninsula) and P-to-S converted phases from the steeply dipping slab. Strong (5-10\%) anisotropy below the Moho in the supra-slab mantle wedge with mostly trench-normal symmetry axes is required to fit most data and is indicative of active deformation of the mantle "lithosphere" beneath the Kamchatka volcanic arc. The authors suggest that mantle strain occurs either by wedge corner flow at depth or by trenchward suction of crust as the Pacific slab retreats.

Karagianni et al. (this volume) use Rayleigh wave group velocity tomography to investigate the crustal structure of continental Greece, the Aegean Sea and 
the eastern Mediterranean subduction area. The nonlinear "hedgehog" inversion, as applied to few local dispersion curves, shows a crustal thickness of approximately $32 \mathrm{~km}$ for the northern Aegean Sea and a relatively thin crust of approximately $22-24 \mathrm{~km}$ for the southern Aegean Sea, a result that is consistent with seismic refraction interpretation (Makris, 1977). In addition to these depth estimates, an S-wave LVZ is found at a depth of $30-40 \mathrm{~km}$, consistent with volcanic activity and high heat flow in the region.

\section{Summary}

We summarize new geophysical evidence for the processes that determine the evolution of the continental lithosphere since the early Archean. These processes are related to plate tectonics and include:

(1) Growth of Precambrian continental lithosphere by collision and accretion of terranes and by subduction, as supported by new seismic interpretations for the Baltic Shield and the western part of the East European Platform.

(2) Growth of Phanerozoic continental lithosphere by continent-ocean collisions, terrane accretion and associated subduction, as evidenced by new seismic tomography results for the Hercynian range in western France, the Alpine-Himalayan belt, the Mediterranean area, and Kamchatka.

(3) Break-up and modification of the continental lithosphere during active or passive continental rifting as illustrated by recent tomographic studies of four modern continental rifts (the Kenya, Baikal, and Rio Grande rifts and the Rhine Graben).

(4) Erosion of the continental lithosphere by mantle convection as illustrated by the analysis of the effect of plate motion on basal drag. Seismic models of rheologically weak LVZs in the upper mantle provide additional constraints for the observed correlation between plate velocities and lithospheric thickness.

(5) Regional and global data on seismic anisotropy provide information on the convection pattern in the upper mantle and on the thickness of the continental lithosphere.

\section{Acknowledgements}

We are grateful to the reviewers of the manuscripts submitted to this special issue for their efforts to keep the high standards of the volume.

Reviewers:

Dallas Abbott (Palisades, NY, USA)

Ulrich Achauer (Strasbourg, France)

Jörg Ansorge (Zürich, Switzerland)

Harmen Bijwaard (Bilthoven, The Netherlands)

Günter Bock (Potsdam, Germany)

Ramon Carbonell (Barcelona, Spain)

Sebastien Chevrot (Cambridge, MA, USA)

Garry Chulick (Menlo Park, CA, USA)

Eric Debayle (Strasbourg, France)

Saskia Goes (Zürich, Switzerland)

Jürgen Gossler (Köln, Germany)

Michel Granet (Strasbourg, France)

Olafur Gudmundsson (Copenhagen, Denmark)

Thomas Hearn (Socorro, NM, USA)

Rainer Kind (Potsdam, Germany)

Vadim Levin (Palisades, NY, USA)
James Mechie (Potsdam, Germany)

Rolf Meissner (Kiel, Germany)

Brian Mitchell (Saint Louis, MO, USA)

Rolf Mjelde (Bergen, Norway)

Lars Nielsen (Copenhagen, Denmark)

Tom Parsons (Menlo Park, CA, USA)

Georges Poupinet (Grenoble, France)

Jeroen Ritsema (Pasadena, CA, USA)

Arthur Rodgers Jr. (Livermore, CA, USA)

Barbara Romanowicz (Berkeley, CA, USA)

Bernd Schurr (Potsdam, Germany)

Nikolai Shapiro (Boulder, CO, USA)

Jeannot Trampert (Utrecht, The Netherlands)

Marc Tittgemeyer (Leipzig, Germany)

Suzan van der Lee (Zürich, Switzerland) 


\section{References}

Abbott, D., Mooney, W.D., 1995. The structural and geochemical evolution of the continental crust: support for the oceanic plateau model of continental growth. Rev. Geophys., Suppl., $231-242$.

Abbott, D., Burgess, L., Longhi, J., Smith, W.H.F., 1994. An empirical thermal history of the Earth's upper mantle. J. Geophys. Res. 99, 13835-13850.

Aki, K., Christofferson, A., Husebye, E.S., 1977. Determination of the three-dimensional seismic structure of the lithosphere. J. Geophys. Res. 82, 277-296.

ANCORP Working Group, 1999. Seismic reflection image revealing offset of Andean subduction-zone earthquake locations into oceanic mantle. Nature 397, 341-344.

Anderson, D.L., 1961. Elastic wave propagation in layered anisotropic media. J. Geophys. Res. 66, 2953-2963.

Anderson, D.L., 1989. Theory of the Earth. Blackwell, Boston, 366 pp.

Ando, M., Ishikawa, Y., Yamazaki, F., 1983. Shear wave polarization anisotropy in the upper mantle beneath Honshu, Japan. J. Geophys. Res. 10, 5850-5864.

Artemieva, I.M., Mooney, W.D., 2001. Thermal structure and evolution of Precambrian lithosphere: a global study. J. Geophys. Res. 106, 16387-16414.

Aulbach, S., Griffin, W.L., Pearson, N.J., O’Reilly, S.Y., Doyle, B.J., Kivi, K., 2001. Re-Os isotope evidence for Meso-Archaean mantle beneath 2.7 Ga Contwoyto Terrane, Slave Craton, Canada: implications for the tectonic history of the Slave Craton. Proc. Slave-Kaapvaal Workshop, Merrickville, Canada, Sept. 5-9, 2001. http://www.cg.nrcan.gc.ca/slave-kaapvaal-workshop/.

BABEL Working Group (Baltic and Bothnian Echoes from the Lithosphere), 1990. Early Proterozoic plate tectonics: evidence from seismic reflection profiles in the Baltic Shield. Nature 348, 34-38.

Bailey, R.C., 1999. Gravity-driven continental overflow and Archaean tectonics. Nature 398, 413-415.

Baldridge, W.S., Keller, G.R., Haak, V., Wendlandt, E., Jiracek, G.R., Olsen, K.H., 1995. The Rio Grande Rift. In: Olsen, K.H. (Ed.), Continental Rifts: Evolution, Structure, Tectonics. Dev. Geotecton., vol. 25. Elsevier, Amsterdam, pp. 233-276.

Bjiwaard, H.W., Spakman, W., Engdahl, E.R., 1998. Closing the gap between regional and global travel time tomography. J. Geophys. Res. 103, 30055-30078.

Bott, M.H.P., 1995. Mechanisms of rifting: geodynamic modeling of continental rift systems. In: Olsen, K.H. (Ed.), Continental Rifts: Evolution, Structure, Tectonics. Dev. Geotecton., vol. 25. Elsevier, Amsterdam, pp. 27-46.

Boyd, F.R., 1989. Compositional distinction between oceanic and cratonic lithosphere. Earth Planet. Sci. Lett. 96, 15-26.

Boyd, F.R., Gurney, J.J., 1986. Diamonds and the African lithosphere. Science 232, 472-477.

Braile, L.W., Keller, G.R., Wendlandt, R.F., Morgan, P., Khan, M.A., 1995. The East African Rift System. In: Olsen, K.H. (Ed.), Continental Rifts: Evolution, Structure, Tectonics. Dev. Geotecton., vol. 25. Elsevier, Amsterdam, pp. 213-232.

Bunge, H.P., Grand, S.P., 2000. Mesozoic plate-motion history be- low the northeast Pacific Ocean from seismic images of the subducted Farallon slab. Nature 405, 337-340.

Burdick, L.J., 1981. A comparison of the upper mantle structure beneath North America and Europe. J. Geophys. Res. 86, 5926-5936.

Calvert, A.J., Sawyer, E.W., Davis, W.J., Ludden, J.N., 1995. Archean subduction inferred from seismic images of a mantle suture in the Superior province. Nature 375, 670-674.

Campbell, I.H., Griffiths, R.W., 1992. The changing nature of mantle hotspots through time: implications for the chemical evolution of the mantle. J. Geol. 92, 497-523.

Carlson, R.W., Shirey, S.B., Pearson, D.G., Boyd, F.R., 1994. The Mantle Beneath Continents. Year Book, vol. 93. Carnegie Inst., Washington, DC, pp. 109-117.

Chase, C.G., Sprowl, D.R., 1983. Proper motions of Pacific-Plate hotspots. Earth Planet. Sci. Lett. 62, 314-320.

Christensen, N.I., Medaris Jr., L.G., Wang, H.F., Jelinek, E., 2001. Depth variation of seismic anisotropy and petrology in central European lithosphere; a tectonothermal synthesis from spinel lherzolite. J. Geophys. Res. 106, 645-664.

Clowes, R.M., Cook, F.A., Ludden, J.N., 1998. LITHOPROBE leads to new perspectives on continental evolution. GSA Today $8,1-7$.

Condie, K.C., 1997. Plate Tectonics and Crustal Evolution. Butterwoth-Heinemann, Oxford. $282 \mathrm{pp}$.

Condie, K.C., 1998. Episodic continental growth and supercontinents: a mantle avalanche convection? Earth Planet. Sci. Lett. 163, 97-108.

Condie, K.C., Chomiak, B., 1996. Continental accretion: contrasting Mesozoic and Early Proterozoic tectonic regimes in the North America. Tectonophysics 265, 101-126.

Cook, F.A., van der Velden, A.J., Hall, K.W., Roberts, B.J., 1999. Frozen subduction in Canada's Northwest Territories: LITHOPROBE deep lithospheric reflection profiling of the western Canadian Shield. Tectonics 18, 1-26.

Davies, G.F., 1995. Penetration of plates and plumes through the mantle transition zone. Earth Planet. Sci. Lett. 133, 507-516.

De Wit, M.J., Roering, C., Hart, R.J., Armstrong, R.A., Ronde, C.E.J., Green, R.W.E., Tredoux, M., Peberdy, E., Hart, R.A., 1992. Formation of an Archean continent. Nature 357, 553-562.

Dziewonski, A.M., 1984. Mapping the lower mantle: determination of lateral heterogeneity in P velocity up to degree and order 6 . J. Geophys. Res. 89, 5929-5952.

Eggler, D.H., Meen, J.K., Welt, F., Dudas, F.O., Furlong, K.P., McCallum, M.E., Carlson, R.W., 1988. Tectonomagmatism of the Wyoming Province. Cenozoic Volcanism in the Southern Rocky Mountains Revisited; A Tribute to Rudy C. Epis. Part 3. Colorado School of Mines Quarterly, 83 (2), 25-40.

EUROBRIDGE Seismic Working Group, 1999. Seismic velocity structure across the Fennoscandia-Sarmatia suture of the East European Craton. Tectonophysics 314, 193-217.

Fukao, Y., 1984. ScS evidence for anisotropy in the Earth's mantle. Nature 309, 695-698.

Fukao, Y., Widiyantoro, S., Obayashi, M., 2001. Stagnant slabs in the upper mantle and lower mantle transition region. Rev. Geophys. $39,291-324$.

Gaherty, J.B., Jordan, T.H., 1995. Lehmann discontinuity as the 
base of an anisotropic layer beneath continents. Science 268 , $1468-1471$.

Gans, P.B., 1987. An open-system, two-layer crustal stretching model for the Eastern Great Basin. Tectonics 6, 1-12.

Grand, S.P., 1994. Mantle shear structure beneath the Americas and surrounding oceans. J. Geophys. Res. 99, 11591-11621.

Griffin, W.L., Andi, Z., O’Reilly, S.Y., Ryan, C.G., 1998. Phanerozoic evolution of the lithosphere beneath the Sino-Korean craton. In: Flower, M.F.J., Chung, S.L., Lo, C.H., Lee, T.Y. (Eds.), Mantle Dynamics and Plate Interactions in East Asia. AGU Geodyn. Monogr., vol. 27, 107-126.

Griffin, W.L., O’Reilly, S.Y., Ryan, C.G., 1999. The composition and origin of sub-continental lithospheric mantle. In: Fei, Y., Bertka, C.M., Mysen, B.O. (Eds.), Mantle Petrology: Field Observations and High Pressure Experimentation. Geochem. Soc. Spec. Publ., vol. 6. Univ. Houston, Dept. Chemistry, Houston, TX, pp. $13-45$.

Griffiths, R., Campbell, I., 1991. Interaction of mantle plume heads with Earth's surface and the onset of small-scale convection. J. Geophys. Res. 96, 18295-18310.

Gu, Y.G., Dziewonski, A.M., Ekström, G., 2001. Preferential detection of the Lehnmann discontinuity beneath continents. Geophys. Res. Lett. 28, 4655-4658.

Gutenberg, B., 1954. Low-velocity layers in the Earth's mantle. Geol. Soc. Am. Bull. 65, 337-347.

Hales, A.L., 1991. Upper mantle models and the thickness of the continental lithosphere. Geophys. J. Int. 105, 355-363.

Herzberg, C., 1995. Generation of plume magmas through time: an experimental perspective. Chem. Geol. 126, 1-16.

Karato, S., 1992. On the Lehmann discontinuity. Geophys. Res. Lett. 19, 2255-2258.

Kaufmann, G., Wu, P., 2002. Glacial isostatic adjustment in Fennoscandia with a three-dimensional viscosity structure as an inverse problem. Earth Planet. Sci. Lett. 197, 1-10.

Kosarev, G., Kind, R., Sobolev, S.V., Yuan, X., Hanka, W., Oreshin, S., 1999. Seismic evidence for a detached Indian lithospheric mantle beneath Tibet. Science 283, 1306-1309.

Kuznir, N.J., Park, R.G., 1984. Intraplate lithosphere deformation and the strength of the lithosphere. Geophys. J. R. Astron. Soc. 79, $513-538$.

Kusznir, N.J., Ziegler, P.A., 1992. The mechanics of continental extension and sedimentary basin formation; a simple-shear/pureshear flexural cantilever model. Tectonophysics 215, 117-131.

Lambeck, K., Smither, C., Johnston, P., 1998. Sea-level change, glacial rebound and mantle viscosity for Northern Europe. Geophys. J. Int. 134, $102-144$.

Lambert, I.B., Wyllie, P.J., 1970. Low-velocity zone of the Earth's mantle; incipient melting caused by water. Science 169, 764-766.

Lehmann, I., 1961. S and the structure of the upper mantle. Geophys. J. R. Astron. Soc. 4, 124-138.

Lehmann, I., 1962. The travel times of the longitudinal waves of the Logan and Blanca atomic explosions and their velocities in the upper mantle. Bull. Seismol. Soc. Am. 52, 519-526.

Lévêque, J.J., Debayle, E., Maupin, V., 1998. Anisotropy in the Indian Ocean upper mantle from Rayleigh- and Love-waveform inversion. Geophys. J. Int. 133, 529-540.
Loper, D.E., Stacey, F.D., 1983. The dynamical and thermal structure of deep mantle plumes. Phys. Earth Planet. Int. 33, 304-317.

Makris, J.A., 1977. Geophysical investigation of the Hellenides. Geophys. Einzelschr. Hamburger 34 (124 pp.).

McKenzie, D., Bickle, M.J., 1988. The volume and composition of melt generated by extension of the lithosphere. J. Petrol. 29, $625-679$.

McLennan, S.M., Taylor, S.R., 1985. The Continental Crust: Its Composition and Evolution Blackwell, Oxford, 312 pp.

Meissner, R., Mooney, W.D., Artemieva, I.M., 2002. Mantle escape inferred from seismic anisotropy in young continental orogens. Geophys. J. Int. 149, 1-14.

Molnar, P., Tapponnier, P., 1975. Cenozoic tectonics of Asia: effects of a continental collision. Science 189, 419-426.

Montagner, J.-P., 1994. Can seismology tell us anything about convection in the mantle? Rev. Geophys. 32, 115-137.

Montagner, J.-P., Tanimoto, T., 1991. Global upper mantle tomography of seismic waves and anisotropies. J. Geophys. Res. 96, 20337-20351.

Nelson, K.D., Zhao, W., Brown, L.D., et al., 1996. Partially molten middle crust beneath southern Tibet; synthesis of Project INDEPTH results. Science 274, 1684-1688.

Nielsen, L., Thybo, H., Solodilov, L., 1999. Seismic tomographic inversion of Russian PNE data along profile Kraton. Geophys. Res. Lett. 26, 3413-3416.

Nishimura, C.E., Forsyth, D.W., 1989. The anisotropic structure of the upper mantle in the Pacific. Geophys. J. 96, 203-229.

Park, J., Levin, V., 2002. Seismic anisotropy: tracing plate dynamics in the mantle. Science 296, 485-489.

Parsons, T., 1995. The Basin and Range Province. In: Olsen, K.H. (Ed.), Continental Rifts: Evolution, Structure, TectonicsDev. Geotecton., vol. 25. Elsevier, Amsterdam, pp. 277-324.

Pearson, D.G., 1999. The age of continental roots. Lithos 48, 171-194.

Pearson, D.G., Carlson, R.W., Shirey, S.B., Boyd, F.R., Nixon, P.H., 1995. Stabilization of Archaean lithospheric mantle; a $\mathrm{Re}-\mathrm{Os}$ isotope study of peridotite xenoliths from the Kaapvaal Craton. Earth Planet. Sci. Lett. 134, 341-357.

Peltier, W.R., 1974. The impulse response of a Maxwell Earth. Rev. Geophys. Space Sci. 12, 649-669.

Percival, J.A., Williams, H.R., 1989. Late Archean Quetico accretionary complex, Superior Province, Canada. Geology 17, $23-25$.

Petit, C., Deverchere, J., Calais, E., San'kov, V., Fairhead, D., 2002. Deep structure and mechanical behavior of the lithosphere in the Hangai-Hövsgöl region, Mongolia: new constraints from gravity modeling. Earth Planet. Sci. Lett. 197, 133-149.

Richards, M.A., Engebretson, D.C., 1992. Large-scale mantle convection and the history of subduction. Nature 355, 437-440.

Richardson, S.H., Harris, J.W., Gurney, J.J., 1993. Three generations of diamonds from old continental mantle. Nature 366, $256-258$.

Ritsema, J., van Heijst, H., 2000. New seismic model of the upper mantle beneath Africa. Geology 28, 63-66.

Romanowicz, B.A., 1982. Constraints on the structure of the Tibet Plateau from pure path phase velocities of Love and Rayleigh waves. J. Geophys. Res. 87, 6865-6883. 
Rudnick, R.L., 1995. Making continental crust. Nature 378, $571-578$.

Savage, M.K., 1999. Seismic anisotropy and mantle deformation: what have we learned from shear-wave splitting? Rev. Geophys. 37, 65-106.

Sengör, A.M.C., Burke, K., 1978. Relative timing of rifting and volcanism on Earth and its tectonic implications. Geophys. Res. Lett. 5, 419-421.

Sengör, A.M.C., Natal'in, B.A., Burtman, V.S., 1993. Evolution of the Altaid tectonic collage and Paleozoic crustal growth in Eurasia. Nature 364, 299-307.

Silver, P.G., Chan, W.W., 1988. Mantle anisotropy and continental evolution. Seismol. Res. Lett. 59 (1), 1-42.

Silver, P.G., Chan, W.W., 1991. Shear wave splitting and subcontinental mantle deformation. J. Geophys. Res. 96, 16429-16454.

Simons, F.J., Zielhuis, A., van der Hilst, R.D., 1999. The deep structure of the Australian continent from surface wave tomography. Lithos 48, 17-43.

Smith, G.P., Ëkstrom, G., 1999. A global study of Pn anisotropy beneath continents. J. Geophys. Res. 104, 963-980.

Stoddard, P.R., Abbott, D., 1996. Influence of the tectosphere upon plate motion. J. Geophys. Res. 101, 5425-5433.

Takei, Y., 2002. Effect of pore geometry on $V_{\mathrm{p}} / V_{\mathrm{s}}$ : from equilibrium geometry to crack. J. Geophys. Res. 107 (B2), ECV6-1-ECV6-12.

Taran, L.N., Bogdanova, S.V., 2001. The Fennoscandia-Sarmatia junction in Belarus: new inferences from a PT-study. Tectonophysics 339, 193-214.

Thybo, H., Perchuc, E., 1997. The seismic $8^{\circ}$ discontinuity and partial melting in continental mantle. Science 275, 1626-1629.

Van der Hilst, R., Karason, H., 1999. Compositional heterogeneity in the bottom $1000 \mathrm{~km}$ of Earth's mantle: toward a hybrid convection model. Science 283, 1885-1888.

Van der Hilst, R., Widiyantoro, S., Engdahl, E.R., 1997. Evidence for deep mantle circulation from global tomography. Nature $386,578-584$.

Van der Lee, S., Nolet, G., 1997. Seismic image of the subducted trailing fragments of the Farallon plate. Nature 386, 266-269.
Van der Voo, R., Spakman, W., Bijwaard, H., 1999a. Mesozoic subducted slabs under Siberia. Nature 397, 246-249.

Van der Voo, R., Spakman, W., Bijwaard, H., 1999b. Tethyan subducted slabs under India. Earth Planet. Sci. Lett. 171, 7-20.

Vinnik, L.P., Green, R.W.E., Nicolaysen, L.O., 1995. Recent deformations of the deep continental root beneath southern Africa. Nature 375, 50-52.

Vinnik, L.P., Chevrot, S., Montagner, J.P., 1998. Seismic evidence of flow at the base of the upper mantle. Geophys. Res. Lett. 25, 1995-1998.

Vinnik, L.P., Chevrot, S., Montagner, J.P., Guyel, F., 1999. Teleseismic travel time residuals in North America and anelasticity of the asthenosphere. Phys. Earth Planet. Int. 116, 93-103.

Warner, M., Morgan, J., Barton, P., Morgan, P., Price, C., Jones, K., 1996. Seismic reflections from the mantle present relict subduction zones within the continental lithosphere. Geology 24, $39-42$.

Woodhouse, J.H., Dziewonski, A.M., 1984. Mapping the lower mantle: three-dimensional modeling of Earth structure by inversion of seismic waveforms. J. Geophys. Res. 89, 5953-5986.

Yale, B.L., Carpenter, S.J., 1998. Large igneous provinces and giant dyke swarms: proxies for supercontinent cyclicity and mantle convection. Earth Planet. Sci. Lett. 163, 109-122.

Yuan, X.et al., 2000. Subduction and collision processes in the Central Andes constrained by converted seismic phases. Nature 408, 958-961.

Zeng, R., Ding, Z., Wu, Q., 1995. A review on the lithospheric structures in the Tibetan Plateau and constraints for dynamics. In: Wang, R., Aki, K. (Eds.), Mechanics Problems in Geodynamics; Part 1. Pure Appl. Geophys. Birkhaeuser Verlag, Basel, Switzerland, pp. $425-443$.

Zhang, Y.-S., Tanimoto, T., 1993. High-resolution global upper mantle structure and plate tectonics. J. Geophys. Res. 98, 9793-9823.

Zielhuis, A., Nolet, G., 1994. Deep seismic expression of an ancient plate boundary in Europe. Science 265, 79-81. 